\title{
Current Methods for Assessing the Level of Foreign Language Proficiency of University Students
}

\author{
Nataliia S. Ivasiv, Mariya S. Kozolup, Olena V. Oleniuk, \\ Nataliia V. Rubel and Nataliya Y. Skiba \\ Ivan Franko National University of Lviv, Lviv, Ukraine \\ https://orcid.org/0000-0001-6243-0709 \\ https://orcid.org/0000-0002-5892-6696 \\ https://orcid.org/0000-0002-6203-9344 \\ https://orcid.org/0000-0003-1924-6580 \\ https://orcid.org/0000-0002-3899-3189
}

\begin{abstract}
The associative technique is a traditional method to estimate a student's foreign language proficiency. The aim of this article is to review the current methods for monitoring and assessing the level of foreign language proficiency of students; the arguments in favour of choosing the associative method of testing for knowledge of lexical semantics; and how assessments are conducted using this method through an associative experiment. The article is based on semantic analysis and field construction of the associative concept at the post-experimental stage. The experiment involved two groups of Ukrainian-speaking students studying German as a foreign language. Each group (control and experimental) consisted of 20 people. The results demonstrate that the assessment of the students' linguistic and communicative competencies requires consideration of parameters in multiple aspects: paradigmatic, syntactic, syntagmatic relations; knowledge of typical idiomatic and phraseological correlations and all possible logicalassociative relations. The experiment revealed shortcomings to include: contamination; weak knowledge of phraseology and moderate ability to establish logical relationships. In order to avoid the above shortcomings, there is a need to use associative experiment in foreign language learning and computer programs to achieve traditional associative learning methods. Lexical-semantic concept analysis revealed different content for semi-peripheral, peripheral and extreme peripheral zones. The article also outlines further promising areas of research, including psycholinguistic and metalinguistic ones. The research is potentially useful for the development of didactic computer programs, for the improvement of associative diagnostic methods in foreign language teaching, etc.
\end{abstract}

Keywords: associative relations; associative experiment; associativesemantic field; monitoring; evaluation 


\section{Introduction}

The assessment of students' human achievements has always been impeded by the difficulty of measuring and determining the relationship between the quantity and quality of socionic knowledge. Since the second half of the 19th century, there have been universal criteria, indicators, and scales developed for assessing the language competencies of future specialists in Europe (Fitzpatrick \& Thwaites, 2020). The result of detailed methodological work was the development of six levels of language proficiency. They have been used since the late 1990s: A1 Breakthrough; A2 - Waystage, B1 - Threshold, B2 - Vantage, C1 Proficiency, C2 - Mastery. A "third wave" of revisions of the principles and methods for assessing foreign language competence is currently taking place, taking into account new digital, communicative and cross-cultural requirements (Turnbull, 2020). This requires new valid methods for diagnosing the quality of language proficiency in the context of bilingualism.

In the context of the humanisation of education, leading governments are revising and transforming traditional test methods that primarily take into account quantitative characteristics of language proficiency: knowledge of grammar rules, the volume of personal vocabulary, and the ability to use language units at the syntagmatic level (McNamara, 2011). Thus, at the Ministerial Conference in Germany in December 2016, the Standing Conference of the Ministers of Education and Cultural Affairs (KMK) recognised that a trilateral approach should be the basis for training foreign language teachers. This approach consists of three dimensions: electronic resources, language communication, and intercultural communication. It can lead to a language-competent person achieving higher-than-expected results (Kultusminister Konferenz, 2017). This approach correlates with metalinguistics, as communication concepts based on both approaches can be both intracultural and cross-cultural (universal) (Serrano, 2011). It is also associated with psycholinguistic types of diagnosis which reveal personal linguistic tools that are built as a result of personality development.

It has become clear that innovative methods for diagnosing foreign language competencies, as well as modern teaching, implement a bottom-up approach (Aristizábal, 2018). This corresponds to the learning and representation of competencies from the native language (natural environment). The diagnostic process itself is intelligent and includes equal and open queries that the student can select and formulate himself (Turnbull, 2020). This determines how modern higher education is monitored, with the prerogative given to self-monitoring and self-regulation (Chang, 2010; Fabriz, Dignath-van Ewijk, Poarch \& Büttner, 2014). One of the problems with university study of a foreign language is a low or satisfactory level of spontaneous and improvised (not on given topics) oral speech (Güzel, 2017). Unfortunately, we found the lowest results for such indicators as: flexibility, lack of tension, and the ability to switch to extraneous topics within the discourse. However, students can show good or excellent knowledge in testing, translation of texts, and knowledge of grammar (Chang, 2011). Obviously, a lack of deep interiorisation of the material, a lack of knowledge of figurative and contextual uses, and, as a result, a lack of naturalness are issues here. Since the 
objective of this study is not the formation but the assessment of foreign language competence, the aim is to find an effective method of testing foreign language competences.

The above considerations confirm the relevance of the study of current methods for assessing the level of foreign language proficiency of university students.

The study intends to review current methods for monitoring and assessing foreign language proficiency among students; the arguments in favour of choosing the associative method for testing knowledge of lexical semantics; and how to conduct an assessment using this method through an associative experiment. Based on the results of the associative experiment, the associativesemantic field for one German language token will be constructed in parallel.

\section{Literature Review}

The system for monitoring the dynamics of foreign language competencies consists of general assessment approaches and principles, assessment methods and a system of expected results. Table 1 presents a broad overview of the variety of scientific approaches to assessment.

Table 1: Basic scientific approaches to the assessment principles as a subject of didactics

\begin{tabular}{|c|c|c|}
\hline Assessment aspect & $\begin{array}{l}\text { Reference to } \\
\text { the source }\end{array}$ & Notes \\
\hline $\begin{array}{c}\text { Application of smart } \\
\text { technologies in teaching } \\
\text { and assessment }\end{array}$ & - & $\begin{array}{l}\text { Program capabilities of in-class control } \\
\text { and self-diagnostics are analysed. }\end{array}$ \\
\hline Diagnosis of motivation & Njiru (2003) & $\begin{array}{c}\text { Academic motivation, confidence, } \\
\text { mobility and flexibility, creative ability } \\
\text { to learn something new are } \\
\text { determined. }\end{array}$ \\
\hline $\begin{array}{l}\text { Monitoring as a didactic } \\
\text { process }\end{array}$ & Mishra (2005) & $\begin{array}{l}\text { In addition to diagnostic function, } \\
\text { monitoring performs didactic } \\
\text { systematising, and repetitive function } \\
\text { in academic data collection. }\end{array}$ \\
\hline Types of assessment & Noh (2006) & $\begin{array}{l}\text { Regardless of the type, actual data are } \\
\text { always subject to assessment. }\end{array}$ \\
\hline $\begin{array}{l}\text { Stages and gradual } \\
\text { assessment of } \\
\text { knowledge quality }\end{array}$ & Mertens (2009) & $\begin{array}{l}\text { Initial, current, intermediate and stage- } \\
\text { by-stage control are distinguished. }\end{array}$ \\
\hline $\begin{array}{l}\text { Comprehensive } \\
\text { diagnostics }\end{array}$ & Kissling (2012) & $\begin{array}{c}\text { This involves complexity of using } \\
\text { teaching and assessment methods, } \\
\text { which are parallel rather than separate } \\
\text { stages. }\end{array}$ \\
\hline $\begin{array}{l}\text { Philosophical basis of } \\
\text { assessment }\end{array}$ & Bibik (2017) & $\begin{array}{l}\text { Regularity, complexity, completeness } \\
\text { and objectivity of the obtained data are } \\
\text { considered to be the main indicators of } \\
\text { acquiring the forecast competencies. }\end{array}$ \\
\hline Self-assessment & Lorenz (2018) & $\begin{array}{c}\text { Creating open resources for self-study } \\
\text { and self-assessment. }\end{array}$ \\
\hline
\end{tabular}




\begin{tabular}{|c|c|c|}
\hline $\begin{array}{c}\text { Mutual assessment in } \\
\text { the course of online } \\
\text { communication }\end{array}$ & Bock (2018) & $\begin{array}{c}\text { This involves team forms of mutual } \\
\text { control based on network } \\
\text { communications. }\end{array}$ \\
\hline $\begin{array}{c}\text { Monitoring within a } \\
\text { determined educational } \\
\text { environment }\end{array}$ & $\begin{array}{c}\text { Goyal (2017); } \\
\text { Siddiqui, Alam, } \\
\text { Khan and } \\
\text { Gupta (2019) }\end{array}$ & $\begin{array}{c}\text { Assessment through free access to } \\
\text { electronic platforms of a particular } \\
\text { educational institution. }\end{array}$ \\
\hline
\end{tabular}

As we can see from the table, evaluation and monitoring correlate as subnotions and generic terms. Assessment refers to determining the quality of specific didactic manifestations and results of activities (facts). Monitoring and assessment also correlate as general and partial (monitoring is carried out through a number of assessment acts). Assessment of knowledge and competencies performs both diagnostic and formative functions. Assessment procedures can be organised externally or by an individual him/herself; it can rely on specific facts, criteria and indicators.

Researchers consider assessment to be the most controversial component of higher education due to various assessment-related problems. In his publication, Purpura (2016) summarised the main problems, contradictions and shortcomings in so-called L2 (Second and Foreign Language) assessment. The research covers current approaches to L2 assessment and predicts their prospects in the future. It also analyses methodological experiences of assessing foreign language knowledge and concludes that knowledge should be assessed in accordance with time requirements; and knowledge should be assessed to make decisions and solve practical problems (Aghababyan, 2016; Aristizábal, 2018; Fitzpatrick \& Thwaites, 2020).

The simplified analysis of the most common assessment types is presented below in the form of dichotomous oppositions (Table 2).

Table 2: Dichotomous classification of current assessment types for foreign language competence

\begin{tabular}{|c|c|}
\hline $\begin{array}{c}\text { Assessment } \\
\text { type }\end{array}$ & Notes \\
\hline $\begin{array}{c}\text { Subjective/ } \\
\text { objective }\end{array}$ & $\begin{array}{c}\text { Subjective assessment always takes place when diagnosing } \\
\text { knowledge in the humanities (it focuses on flexibility, } \\
\text { expressiveness, and a general impression produced by the speaker). }\end{array}$ \\
\hline $\begin{array}{c}\text { Quantitative/ } \\
\text { qualitative }\end{array}$ & $\begin{array}{c}\text { Quantitative indicators are easily diagnosed through testing, } \\
\text { listening and translation, while non-linear means, syntagmatic } \\
\text { range, and communicative efficiency require qualitative } \\
\text { parameters. }\end{array}$ \\
\hline $\begin{array}{c}\text { Continuous / } \\
\text { at a certain } \\
\text { time }\end{array}$ & $\begin{array}{c}\text { Continuous types of assessment include self-assessment, current in- } \\
\text { class control. }\end{array}$ \\
\hline $\begin{array}{c}\text { Formative and } \\
\text { summarising }\end{array}$ & $\begin{array}{c}\text { Any detailed assessment is also a formative factor. The final types } \\
\text { include all types of academic control (stage-by-stage control, } \\
\text { modular, etc). }\end{array}$ \\
\hline
\end{tabular}




\begin{tabular}{|c|c|}
\hline $\begin{array}{l}\text { Relative to the } \\
\text { criterion / } \\
\text { relative to the } \\
\text { norm }\end{array}$ & $\begin{array}{l}\text { The criteria selected for different language styles may also contain } \\
\text { obscene components (slang, jargon, individual word usage). }\end{array}$ \\
\hline $\begin{array}{l}\text { Partial / } \\
\text { aggregate }\end{array}$ & $\begin{array}{l}\text { In a partial assessment, certain aspects, such as pronunciation, are } \\
\text { subject to testing. }\end{array}$ \\
\hline $\begin{array}{l}\text { Direct / } \\
\text { indirect } \\
\text { assessment }\end{array}$ & $\begin{array}{l}\text { In direct assessment, the teacher perceives the student's discourse } \\
\text { directly. In indirect assessment, the teacher studies results } \\
\text { presented in the form of written work and project presentations. }\end{array}$ \\
\hline $\begin{array}{l}\text { By rational } \\
\text { criteria / by } \\
\text { impression }\end{array}$ & $\begin{array}{l}\text { Impression-based assessment is more holistic and focuses mainly } \\
\text { on nonverbal aspects (speech rate, intonation, lack of tension, etc). }\end{array}$ \\
\hline $\begin{array}{l}\text { Assessment of } \\
\text { performance / } \\
\text { skill }\end{array}$ & $\begin{array}{c}\text { Assessment of skill is used at higher levels of language proficiency } \\
\text { or in the creative (artistic) use of a foreign language. }\end{array}$ \\
\hline $\begin{array}{l}\text { By others / } \\
\text { self- } \\
\text { assessment }\end{array}$ & $\begin{array}{l}\text { The combination of external assessment and self-assessment is most } \\
\text { in line with the modern personality-oriented approach. }\end{array}$ \\
\hline $\begin{array}{l}\text { ëAnalytical / } \\
\text { holistic }\end{array}$ & $\begin{array}{l}\text { Analytical assessment allows you to assess individual parameters } \\
\text { (knowledge of grammar rules, pronunciation, personal vocabulary). } \\
\text { Holistic assessment gives an overall impression of an individual's } \\
\text { knowledge of the relationship of different parameters and a general } \\
\text { impression of language proficiency. }\end{array}$ \\
\hline $\begin{array}{l}\text { By skills / by } \\
\text { activity } \\
\text { performed }\end{array}$ & $\begin{array}{l}\text { This opposition to assessment correlates with a process and an } \\
\text { outcome. For example, a student speaks well but does not achieve } \\
\text { communication goals well. }\end{array}$ \\
\hline
\end{tabular}

Source: Author's research

Among the modern methods of testing students' foreign language competence, the test approach still dominates. However, modern tests are significantly different from classic ones: they are mostly open, flexible, focused on current knowledge and meet four criteria: validity, authenticity, reliability and positive "washback" (Aristizábal, 2018). Moreover, the concept of "washback" is becoming more common in didactics. It refers to formative and motivational feedback from the performance of diagnostic tasks.

Currently the tools and conceptual framework for monitoring linguistic education are well developed. Discussions mainly centre around its effectiveness and validity: managerial effectiveness when monitoring teaching and learning in school didactics (Mngomezulu, 2015); and methods of assessing university and extracurricular management effectiveness (Victoria Primary School, 2018).

As part of a diagnostic experiment in non-linguistic specialties, scientists propose to test, first, communicative competence. Such assessment contains informational, organisational, regulatory and communicative components. Assessment criteria and methods based on these aspects are selected.

Mathematical methods, quality assessment methods and graphical presentation of the results are widely used in modern knowledge monitoring. The stages of modern students' knowledge monitoring, according to Hoover (2009), are presented in Table 3. 
Table 3: Stages of modern monitoring of knowledge

\begin{tabular}{|c|c|}
\hline $\begin{array}{c}\text { Knowledge } \\
\text { monitoring stage }\end{array}$ & Explanation \\
\hline Criterial & $\begin{array}{l}\text { Identification of competencies, criteria and indicators of their } \\
\text { manifestation. }\end{array}$ \\
\hline Instrumental & $\begin{array}{l}\text { Development or selection of valid and compact methods over } \\
\text { time and techniques for identifying competencies. }\end{array}$ \\
\hline Algorithmic & Development of a monitoring program and its planning in time. \\
\hline Procedural & $\begin{array}{c}\text { Conducting monitoring taking into account the results of } \\
\text { training in the previous stages. }\end{array}$ \\
\hline Presentational & $\begin{array}{l}\text { At this stage, the assessment results are presented after } \\
\text { mathematical development by means of visualisation (graphs, } \\
\text { charts, digital data). }\end{array}$ \\
\hline Progressive & $\begin{array}{c}\text { This is to determine the dynamics, and positive or negative } \\
\text { changes in language competences according to criteria and } \\
\text { indicators. }\end{array}$ \\
\hline Corrective & $\begin{array}{l}\text { Adjustments are made to the educational process based on the } \\
\text { results of the analysis of dynamics. }\end{array}$ \\
\hline Permanent & $\begin{array}{c}\text { This consists of planning and regularly conducting the next } \\
\text { stages of monitoring or self-monitoring. This stage is } \\
\text { permanent. }\end{array}$ \\
\hline
\end{tabular}

Source: Hoover (2009)

The literature discusses the gradual departure from traditional approaches to testing grammar and vocabulary knowledge (Siddiqui et al., 2019). Testing (closed and open) is supplemented by elements of constructing spontaneous oral and written speech, and establishing the volume of learned meanings and associations (Turnbull, 2020). Assessment of foreign language competencies should be diagnostic and formative, and the main element of diagnosed skills should be communicative. This approach allows knowledge to be tested, and conclusions to be drawn about the acquisition of bilingual status by students, even those who study a foreign language on their own (Turnbull, 2020).

Modern linguodidactics considers a foreign language in the context of bilingualism and translanguaging. A truly bilingual person has the ability to authentically and naturally speak his native and foreign languages (Creese, Blackledge \& Takhi, 2014; García \& Wei, 2014). They study issues relating to epistemological (scientific) approaches to the transformation of linguistic education in the context of native languages (García, 2019) such as mastering a foreign language before obtaining a degree (in the context of scientific propaedeutics). Kaplow (2017) believes that specialised competencies in a foreign language can be considered valid and sufficient when the native speaker can read a complex scientific text, argue and verify the facts for authenticity. Competencies sufficient in a case include a speaker being able to put forward hypotheses, prove them and draw conclusions. A competent speaker can participate in scientific discussions and illustrate theory with examples, demonstrate contexts, clarify and formulate epistemes as basic units of scientific knowledge. 
This raises the problem of finding the best overall method of assessing foreign language competence or several methods that could complement each other. Modern scholars, on the basis of their experience, indicate that associative experimentation may be such a method. It can be both diagnostic and formative. According to Khirzoeva (2008), such an experiment diagnoses not only knowledge of a foreign language, but also flexibility in thinking, the ability to establish syntagmatic and paradigmatic relations, to feel the peripheral semantics of tokens and to use linguistic richness to generate coherent oral text. Research on association experiment began to be developed in the nineteenth century (Fitzpatrick \& Thwaites, 2020). German scholars were the first to propose associative experimentation as a method of studying and diagnosing language competencies in the early 20th century (Fitzpatrick \& Thwaites, 2020). It correlates with the theory of neural connections (neurolinguistics), the theory of functional fields, cognitive linguistics, sociolinguistics, and other theories. The closest linguistic theory that complements this experiment is mental linguistics. According to that approach, key concepts together with a set of logical, metaphorical, associative and other linguistic connections make up the lexicalsemantic field (concept). The lexical-semantic concept can be considered a common language (national concepts) or a personal (personal concepts) formation.

\section{Methodology}

Foreign language proficiency depends on a student's individual mental development, the richness of his/her native individual style, and the formation of thinking based on deep knowledge of the native language. These processes develop in a linear way through connection of the referent and its verbal objectification. Such a relationship can be diagnosed in a fast, indirect mode using the associative method as an element of tests or as a separate didactic experiment. According to scholars (Fitzpatrick \& Thwaites, 2020), such an experiment reveals not so much semantic connections in students as connections between external stimuli-irritants, which are instantly verbalised (Khirzoeva, 2008). The associations' speed and range allow conclusions to be drawn about the quality of an individual's knowledge and the degree to which foreign language units have been internalised.

A simplified dichotomous approach to linguistic professional competencies reduces the number of criteria to two: knowledge of language units (language) and mastery of language units (language). While the first level of achievement is easily diagnosed through tests, translation of written texts and listening (representative level), the second requires a more personal and irrational approach. Acquiring foreign language competencies means using them similarly to the native language to the maximum possible extent. Cognitive learning of the native language is well diagnosed by constructing concepts in the form of a lexicosemantic field or, using an associative experiment, an associative-semantic field. Since the authors do not research natural mastery of a foreign language during studies for a bachelor's degree, this article proposes that an associative structure of the word should be built by analogy with the structure of the concept. The 
associative structure process will be final in the reflection of the associative experiment.

The experiment involved two groups of Ukrainian-speaking students studying German as a foreign language. They were in their first year of a bachelor's degree (control group) and the fourth year of a bachelor's degree (experimental group). Each group (control and experimental) consisted of 20 people. This choice was due to the gradual expansion of personal experience in the use of the most commonly used words over time. The set of tokens selected for analysis during the associative experiment was mandatory for basic proficiency at both level A2 (first year) and level B2 (fourth year). Such a set of tokens means that the participants in both the control and experimental groups have approximately the same knowledge of at least the primary meanings of these tokens. Therefore, the experiment was designed not so much so that individuals could recognise the meaning, but to clarify conceptuality (of words as concepts) and the scope of meaning.

After obtaining the results of the assessment in the associative experiment, the authors used the semantic analysis method. Such an analysis clarifies the relations that students have established between tokens. The authors also applied a field modelling method to the associative concept of individual tokens based on the results of these relations.

\subsection{The Course of the Experiment}

An associative experiment assessed foreign language competencies and determines the coefficient of bilingualism at the Faculty of Foreign Languages for specialisations where the main language was German. From the thesaurus of the most commonly used meaning-bearing words (over 5,500), 40 tokens were selected (nouns, adjectives and verbs in approximately equal proportions) by random sampling (random machine generation). The authors informed participants about the experiment and they gave verbal consent to participate in it. After that, the teacher read the tokens in a random order, and the students had 5-7 seconds to write down the blitz associations. There was no maximum limit for this; they ranged in number from 2 to 5 for the control and experimental groups. The second stage of the experiment involved collection of the maximum number of associations for a limited number of tokens with no time limit. The aim was to find out the language-associative competencies and levels of students' personal language vocabulary for the control and experimental groups. The second stage also intended to collect lexical associative material to construct an associativesemantic field for a widely used token in the German language. At this stage, we offered each student one token and an unlimited amount of time (up to an hour or more). The student had the opportunity to comprehend and arbitrarily explain the meaning and essence of the selected associations. At this stage, we clarified the maximum scope of the individual concept.

The authors selected the respondent's age category according to the most relevant neurodidactic indicators. Thus, late adolescence and early preadult age were relevant to the acquisition of linguistic richness. At this time, a person's linguistic 
personality, his verbal tools are formed and language acquisition includes a range of meanings, uses and images that make up a personal individual style.

The third stage of the research involved concept construction based on all the maximum possible meanings of a single word and determination of its associative and subjective meanings. Such meanings have a relatively weak correlation with their primary lexical and semantic variants, so they illustrate logical and emotional thinking (emotional intelligence) by type of native language. The authors applied the free associations method proposed by Sternin (2001) in order to carry out an inductive assessment on language proficiency on the basis of the analysis of rare lexical-semantic variants. The researcher proposed to make an inventory of linguistic and non-linguistic associations, to establish types of connections and to explain their origin from the point of view of personal development (formation). All types of associative words and their relations were taken into account. After data collection, we constructed the associative-semantic field for the token Fabel (fairy tale). Figure presents the results for that construction (see Appendix A).

Thus, during the experiment the authors assessed the personal foreign language competencies of participating students in their early and final stages of study. The article structured one of the concepts in the mind of a modern student.

\section{Results}

The analysis of methodological sources allowed a number of preliminary preexperimental conclusions to be drawn. Thus, modern foreign language competencies consist of two key components. The first is a social order and the second is personal orientation. Both components can have a narrow specialisation (agricultural translation, technical translation, guide-translator), but must include intercultural (sociocultural) orientation. The latter is associated with the acquisition of relevant political, social, artistic, ethical, communication knowledge. The initial competence involves intercultural communication skills. A full assessment of foreign language competence should consistently take into account the following gradation aspects: personal prerogatives - mandatory program requirements - interpersonal communication - intercultural communication - intercultural dialogue - dialogue of cultures.

Psycholinguistic indicators of foreign language proficiency result from an assessment of vocabulary diversity within the areas of discourse, the volume of speech production, the average or appropriate size of sentences (depending on speech style), the inclusion of clichés, speech stereotypes, word-parasites (the less, the better), and the ratio of verbs to the total number of tokens. These indicators make up so-called "verbal intelligence". In fact, the psychological indicators are spontaneity, richness of associations and involvement of words from related topics, emotional inspiration and personal orientation (Khirzoeva, 2008).

Mentalinguistics (the doctrine of language concepts) correlates with the actual psycholinguistic approach to teaching and assessing individuals' knowledge of foreign languages. A number of subjective, connotative and associative meanings 
in the mind of a native speaker of a foreign language, along with the denotative meaning, indicate the relative completeness (sufficiency) of the vocabulary available to an individual. Students should develop knowledge of foreign words not in the form of one- or multi-component definitions, but concepts.

A concept is a psycholinguistic individual and group formation that contains all the paradigmatic, syntagmatic, and possible associative relations of a single notion. Field construction of the concept helps to distinguish the center, semiperiphery, periphery and extreme periphery (up to subjective associations that cannot be explained extrovertedly).

Qualitative and quantitative assessment methods can be applied using psycholinguistic and mentalinguistic approaches in the analysis of the initial experimental data. This assessment is based on an associative method for determining the meanings selected from a foreign language glossary, which is mandatory for a student at this stage of study. In this regard, scholars note that results in the study of the humanities are monitored using quantitative data only initially and in an auxiliary way. The very dynamics of competencies can only be measured as quality dynamics in the context of other competencies $(\mathrm{Hu}, 2002)$.

During the first part of the experiment, students in the control and experimental groups were offered a number of meaning-bearing words in German. First-order associates (selected during the first seconds) included one to two, less often three, lexico-semantic variants, typical syntagmatics, standard expressions (clichés, less often phraseological units), personal associations, etc.

Before the first part of the diagnostic experiment (selection of blitz associations) was undertaken, we arranged the types of meaning according to their complexity: direct meaning - typical syntactics - typical syntagmatics - lexico-semantic variants - derivational relations - figurative meanings - phraseologically related meanings - free associations - subjective meanings. Hypothetically, the degree of associative complexity increases in such a series. Thus, this ranking can determine fluency level in terms of the vocabulary. We assessed of the varied associative use of tokens by scoring them from 1 to 9 (according to the number of components from the above ranking used).

The graph (see Appendix B) shows that a higher rank correlated with less success in terms of assignment completion in the experimental group. However, an increase in extremes reflects figurative meanings, the selection of free associations, and the subjective meaning of a word. This testifies to the moderation of logical relations and knowledge of typical usages, and proves the validity of the thesis about the dominance of emotional, subjective and personal word usage. Students often find associations both within the syntagmatic laws of the German language and by analogy with the native language. Sometimes this is detrimental to a normative phraseologically or syntagmatically related meaning, because these meanings may not coincide in different languages.

Unfortunately, we identified a number of negative trends during the experiment. They were caused by semantic contamination, literal translation, ignorance of 
lexical and semantic variants, calquing at the level of words and phraseologism, etc. The main conclusions after the first part of the experiment (selection of blitz associations) are as follow:

1. In the control groups, $75 \%$ (15 people) gave only 1-2 lexico-semantic variants of meaning-bearing words.

2. Some associations indicated a literal translation of a word or cliché into German. For example, students chose the lexico-semantic associations breaking stereotypes, persuading someone, playing hard-to-get (slang) for the verb brechen (break). Such analogies do not correspond to German language laws and are, in fact, calques from Ukrainian.

3. Some associations (approx. $7 \%$ ) related to paronomasia - a similar, but not related meaning in terms of word creation: dick (thick), deckel (cover), dichte (density) etc. These are formal associations that do not correspond to any semantic or word-forming correlations. Therefore, we need to carefully analyse free associations, as some of them are not valid.

The results of the second part of the experiment give a generalised picture of the knowledge and associative abilities of students in the experimental and control groups. Semantic analysis of these results (establishment of meaning, paradigmatic, syntagmatic and associative relations) allowed the results to be presented in the form of a table indicating the mechanism of associations, the frequency of their manifestation and examples (Table 4).

Table 4: Classification of typical associations found during the experiment on the example of the token Die Wand (wall)

\begin{tabular}{|c|c|c|c|}
\hline \multirow{2}{*}{$\begin{array}{l}\text { Type of association } \\
\text { and/or its mechanism }\end{array}$} & \multirow{2}{*}{ Examples } & \multicolumn{2}{|c|}{ Number of students } \\
\hline & & EG & CG \\
\hline $\begin{array}{l}\text { Hypo-/hyperonymic } \\
\text { relations }\end{array}$ & $\begin{array}{c}\text { Die Wand - das Gebeude, Wall } \\
\text { - structure }\end{array}$ & 18 & 16 \\
\hline $\begin{array}{l}\text { Part of the whole } \\
\text { (synecdoche) }\end{array}$ & $\begin{array}{c}\text { Die Wand - das Haus, Wall - } \\
\text { house }\end{array}$ & 17 & 14 \\
\hline Antonymous association & $\begin{array}{c}\text { Die Wand - die Zerstörung, } \\
\text { Wall - ruin }\end{array}$ & 11 & 7 \\
\hline Association by function & $\begin{array}{c}\text { Die Wand - hangen, Wall - } \\
\text { hang up }\end{array}$ & 13 & 8 \\
\hline Spatial contiguity & $\begin{array}{c}\text { Die Wand - das Bild, Wall - } \\
\text { picture }\end{array}$ & 16 & 14 \\
\hline Predicative association & $\begin{array}{c}\text { Die Wand wird gebaut (steht), } \\
\text { Wall is under construction } \\
\text { (stands) }\end{array}$ & 14 & 10 \\
\hline $\begin{array}{l}\text { Association by subsection } \\
\text { relations }\end{array}$ & $\begin{array}{l}\text { Die Wand - das Dach, das } \\
\text { fundament, Wall - roof, } \\
\text { foundation wall }\end{array}$ & 13 & 8 \\
\hline
\end{tabular}




\begin{tabular}{|c|c|c|c|}
\hline By similarity (metaphor) & $\begin{array}{c}\text { Die Wand - das Hindernis, der } \\
\text { Schirm, Wall - barrier, } \\
\text { obstacle, shield }\end{array}$ & 18 & 16 \\
\hline Paronomasia (consonance) & $\begin{array}{c}\text { Die Wand - die Wende, Wall - } \\
\text { boundary }\end{array}$ & 11 & 8 \\
\hline Grammatical transposition & $\begin{array}{c}\text { Die Wand - wandlich, Wall - } \\
\text { wall-mounted, wall-type }\end{array}$ & 10 & 7 \\
\hline $\begin{array}{c}\text { Connotative (evaluative) } \\
\text { judgment }\end{array}$ & $\begin{array}{c}\text { Stark wie ein Wand - strong } \\
\text { as a wall }\end{array}$ & 5 & - \\
\hline $\begin{array}{c}\text { Phraseologically related } \\
\text { association }\end{array}$ & $\begin{array}{c}\text { Sich wie ein Mann erheben - } \\
\text { make a stand for }\end{array}$ & 7 & 3 \\
\hline $\begin{array}{c}\text { Idiomatically related } \\
\text { association }\end{array}$ & $\begin{array}{c}\text { Die Wand - Die Berliner } \\
\text { Wand, Wall - Berlin Wall }\end{array}$ & 6 & 4 \\
\hline $\begin{array}{c}\text { Association by property, } \\
\text { feature }\end{array}$ & $\begin{array}{c}\text { Die Wand - Die starke Wand, } \\
\text { Wall - strong wall }\end{array}$ & 4 & 4 \\
\hline Determinant relations & $\begin{array}{c}\text { Die Wand - bauen, zerstören, } \\
\text { Wall - build, destroy }\end{array}$ & 7 & - \\
\hline
\end{tabular}

According to the results shown in Table 4, the following preliminary conclusions about the second stage of the associative experiment are made:

1. Students in the experimental group found more associations than students in the control group;

2. All students in the control and experimental groups found a wide range of attributive, predicative associations, as well as hypo-/hyperonymy relationships; "part of the whole" relations; associations by function and by subsection relations. This indicates flexibility in thinking, even among the first-year students.

3. The students in the control group did not find any paronomastic and phraseological relations, which indicates less knowledge of vocabulary and phraseology at the initial stage of learning.

4. Students in both groups showed equally weak (satisfactory) competencies in establishing relations by similarity (metaphor), associations by subsumption, grammatical transpositions, connotative (evaluative) judgments, idiomatically related associations, associations by property (feature) and determinant relations. This indicates a low level of functional use of lexical units.

5. All students found consistent associations by analogy with their native (Ukrainian) language. This aspect needs to be addressed didactically, as figurative and phraseologically related meanings are different in different languages.

Linguistic interference must be weakened in the process of acquiring foreign language competencies.

In this regard, we recommend improving the content of curricula in terms of functional linguistics and phraseology by including an associative experiment in the didactic tools (educational, not just diagnostic). There is a need to intensify the study of typical syntagmatic, clichéd, phraseological word usages in the German language. 
The result of the third part of the experiment involved the construction of an associative-semantic concept in the form of a field. Figure (Appendix A) shows the structure and content of this concept for the example of the token Fabel (fable, plot).

Figure (Appendix B) shows the quantitative and qualitative content of the associative-semantic concept as summarised by the experimental group. Let us analyse the structure of the associative field of the token Fabel (fairy tale).

1. Level (core) - the primary meaning, as well as basic lexical and semantic variants. In the form of synonyms, they can be rendered by two representatives - a fable, a plot. Overall, 17 out of 20 students showed knowledge of these secondary meanings.

2. Level (semi-periphery) - the ratio of hypo- and hyperonymy folklore, fiction, lies, literature. Most students perceived these associates as synonyms, although they are related generally and partially by presupposition: each fairy tale is folklore; every fairy tale is a fiction, and so on.

3. Level (periphery) - figurative meanings and related actions (metonymy): forgery, tell, untruth, transformation, listen, charming, Grimm brothers, legend, good, myth, curiosity. This zone turned out to be the most productive, which indicates a high level of metaphorical and metonymic mechanisms in the reflected pictures of the concept by students in both groups.

4. The level of typical associations (victory, ancient, believe, childhood, seven, three, past, doubt, hero) is quantitatively limited, which indicates a weak development of associative-logical thinking with the number of logical or associative links over 2 .

5. The level of occasional associations (outside the concept: fear, childhood, evening, wolf, comfort, remember, end, joy, mother, country) is quantitatively open and varies depending on the student. The development and significant fullness of this outside-the-concept zone indicates the dominance of subjective meanings and associations.

6. The number of students who selected associates is declining in the direction of the periphery. In the area of outside-the-concept subject associations, the number of associations increases. The number of students who selected them also increases. The selection of phraseologically related meanings, which imply knowledge of stable expressions, rather than an association between tokens, is particularly difficult.

\section{Discussion}

The obtained results correlate with a number of similar studies on foreign and native languages. Associative experimentation is a part of foreign language competence development and diagnostics. It is a tool for constructing a concept or associative-semantic field for the native language (Mubarakshina, Fedorova \& Fattahova, 2016). This testifies to the wide functionality of the associative method in the humanities.

The presented results and the principles indicate the essence of associative experimentation and previous discourse confirmed the using sense language theory and practice by students or those who acquire foreign language skills. The 
main indicator of this approach is the dynamics of students' sense of language; such dynamics are regularly assessed using the associative experimentation method (Aghababyan, 2016).

The data obtained as a result of the experiment have demonstrated the possibilities of an associative experiment for constructing universal, national and personal concepts in the form of an associative-semantic field, which extends from lexico-semantic variants (core) to the far periphery (the latter contains subjective associations with the original token). The word association technique is a basis for exploration of lexicon content and structure, and can be used as a method for understanding the bilingual brain, and a technique for assessing vocabulary knowledge, among other research aims (Fitzpatrick \& Thwaites, 2020).

Based on the associative experiment results that record and evaluate a student's sense of language, this research indicates an effective assessment method for the development of foreign language competence. For this, the student would learn the obligatory paradigmatic relations, gain experience in establishing typical associations during training and communication, and generate new relations during professional activity (Aghababyan, 2016). Flexible use of connections is possible in a formative associative experiment, involving the first word-reaction, the second word-reaction and the whole chain of self-consistent associations, each following from the previous one. This is how associative-semantic memory is formed.

As a result of generalisations of experimental data, the research has proved that the connection between thematic relations and conceptual representations for particular concepts does not always coincide, since there are individual differences. However, both vertical and horizontal relations between a word and its associates play an important role in the development of semantic memory, and these associations complement each other and contribute to the spontaneous unprepared generation of a new text (Mukhametzyanova \& Shayakhmetova, 2014).

The experiment revealed the negative aspects of the associative method in assessment, and especially in training. Rose and Rahman (2016) predicted that the constant use of the associative method leads to semantic interference between associations (mixing of meanings) and cumulative (directed to a particular aspect) selection of associations. Negative effects from an associative experiment can be avoided by encouraging students to change contexts, to select associations in terms of expansion, rather than deepening subsumptive semantics.

Associative relations between language elements can be used not only as a methodological tool, but also a way to study semantic processes: connotation, language interference and individual language modality (individual style). The cumulative effect of associative fields, units of which stimulate the emergence of an increasing number of associations in a certain direction, was confirmed by means of an associative experiment (Rose \& Rahman, 2016). This effect can be 
used in linguodidactics: new tokens will be layered on the knowledge of tokens of a certain semantic field in the process of applying the associative method.

\section{Conclusion}

The associative method is the most valid tool for undertaking a comprehensive knowledge check of lexical material and foreign language competence for a student assessment. The associative experiment has been demonstrated to be a universal tool that allows assessment and the formation of foreign language competencies, while providing valuable material for constructing associativesemantic fields for particular tokens. This could be a starting point for constructing lexical concepts in the language consciousness of young students. The diagnostic part found that students in the experimental group completed the assignment for the selection of associations 15\% better than the control group. At the same time, we revealed that there were a number of shortcomings of Ukrainian-speaking students in learning a foreign (German) language. This applied to both the control and experimental groups. Most of the shortcomings related to native language analogies and ignorance of typical associations in German. Thus, further methodological improvements in German language research are required. The constructed associative-semantic field for the Fabel token showed that the peripheral zone and the zone of subjective associations are the most developed, which indicates a sufficient syntagmatic level of word usage and a developed subjective meaning. At the same time, paradigmatic relations and remote periphery indicate the need for active work with the vocabulary and the development of logical relations between denotations. Further research on this topic could develop software to automate the associative experiment, and could supplement this type of assessment with others (establishing paradigmatic relations between words, the use of words in context, etc). Associative methods of teaching foreign vocabulary and phraseology also need further development.

\section{References}

Aghababyan, K. H. (2016). Investigation of dynamics of students' sense of language by word associative experiment method. In R. Draut (Ed.), Humanities in the 21st century: scientific problems and searching for effective humanist technologies (pp. 55-62). San Francisco, CA: B\&M Publishing.

Aristizábal, G. F. (2018). A diagnostic study on teachers' beliefs and practices in foreign language assessment. Íkala, Revista de Lenguaje y Cultura, 23(1), 25-44. https://doi.org/10.17533/udea.ikala.v23n01a04

Bibik, N. M. (2017). New Ukrainian school: teacher's advisory book. Kyiv, Ukraine: TOV "Vydavnychy dim 'Pleyady'".

Bock, A. (2018). The transformation of school textbooks into digital educational media. Retrieved from https:/ / repository.gei.de/handle/11428/291

Chang, M. M. (2010). Effects of self-monitoring on web-based language learner's performance and motivation. Calico Journal, 27(2), 298-310.

Chang, S. C. (2011). A contrastive study of grammar translation method and communicative approach in teaching English grammar. English language teaching, 4(2), 13-24. https://doi.org/10.5539/elt.v4n2p13

Creese, A., Blackledge, A., \& Takhi, H. K. (2014). The ideal 'native speaker' teacher: negotiating authenticity and legitimacy in the language classroom. The Modern Language Journal, 98(4), 937-951. https://doi.org/10.1111/modl.12148 
Fabriz, S., Dignath-van Ewijk, C., Poarch, G., \& Büttner, G. (2014). Fostering selfmonitoring of university students by means of a standardized learning journal a longitudinal study with process analyses. European Journal of Psychology of Education, 29(2), 239-255. https://doi.org/10.1007/s10212-013-0196-z

Fitzpatrick, T., \& Thwaites, P. (2020). Word association research and the L2 lexicon. Language Teaching, 53(3), 237-274. https://doi.org/10.1017/S0261444820000105

García, O. (2019). Reflections on Turnbull' s reframing of foreign language education: bilingual epistemologies. International Journal of Bilingual Education and Bilingualism, 22(5), 628-638. https://doi.org/10.1080/13670050.2016.1277512

García, O., \& Wei, L. (2014). Translanguaging: language, bilingualism and education. Basingstoke, UK: Palgrave Macmillan.

Goyal, A. (2017). 8 benefits of adopting cloud-based applications in education. Retrieved from https://elearningindustry.com/cloud-based-applications-in-education-8benefits

Güzel, M. Ç. (2017). Developing oral proficiency and motivation through script-based and improvisational drama (unpublished master's thesis). California State University, San Bernardino, CA.

Hoover, J. J. (2009). RTI assessment essentials for struggling learners. Thousand Oaks, CA: Corwin Press.

Hu, G. (2002). Potential cultural resistance to pedagogical imports: The case of communicative language teaching in China. Language Culture and Curriculum, 15(2), 93-105. https:// doi.org/10.1080/07908310208666636

Kaplow, I. (2017). "Fachspezifische Fremdsprachenkenntnisse“ und Wissenschaftliche Propädeutik ["Subject-specific foreign language skills" and scientific propaedeutics]. Berlin, Germany: Berlin Catholic University of Social Sciences.

Khirzoeva, Z. M. (2008). Associative experiment as a method of ranking the foreign language proficiency level. Proceedings of Dagestan State Pedagogical University, 3, 16.

Kissling, E. M. (2012). Techniques and principles in language teaching, third edition (book review). Retrieved from https://pdfs.semanticscholar.org/b9fb/e8d83b069c57deec5aa1a8967f085fb7664 b.pdf

Kultusminister Konferenz. (2017). The standing conference's "Education in the digital world" strategy summary. Retrieved from https://www.kmk.org/fileadmin/Dateien/pdf/PresseUndAktuelles/2017/KM K-Strategie_Bildung_in_der_digitalen_Welt_Zusammenfassung_en.pdf

Lorenz, A. (2018). Eine offene Bildungsressource (OER) ist konsequent eingesetzt eine Chance für den Hochschulzugang: ein Praxisbericht [An open educational resource (OER) is consistently used an opportunity FOR university admission: a practical report]. Medien Pädagogik: Zeitschrift für Theorie Und Praxis Der Medienbildung (Offenheit in Lehre und Forschung), 32, 28-40. https://doi.org/10.21240/mpaed/32/2018.10.21.X

McNamara, T. (2011). Authority and language assessment. Language Teaching, 44(3), 39-52.

Mertens, D. M. (2009). Research and evaluation in education and psychology. London, UK: SAGE Publications Inc.

Mishra, R. C. (2005). Educational research. New Delhi, India: A.P.H. Publishing Corporation.

Mngomezulu, N. M. (2015). Strategies of monitoring teaching and learning: A school management team perspective (unpublished master's thesis. School of Education in the discipline, Educational Leadership, Management and Policy, University of Kwazulu-Natal, Durban, South Africa). Retrieved from 
https://pdfs.semanticscholar.org/ad88/c69af2852be19f4c0ab1c47f961ef4619ad4. pdf

Mubarakshina, A., Fedorova N., \& Fattahova, N. (2016). Associative-semantic field of "nravstvennost" in modern Russian language. Journal of Language and Literature, $7(2), 280-284$.

Mukhametzyanova, L., \& Shayakhmetova, L. (2014). Application of associative experiment in forming the foreign communicative competence. English Language Teaching, 7(12), 60-64. https://doi.org/10.5539/elt.v7n12p60

Njiru, J. N. (2003). Measuring academic motivation to achieve for high school students using a Rasch measurement model (unpublished master's thesis. Faculty of Community Services, Education and Social Sciences, Edith Cowan University, Perth, Australia). Retrieved from https://ro.ecu.edu.au/theses/1320/

Noh, H. J. (2006). Policy evaluation. Seoul, Korea: Bupmunsa.

Purpura, J. E. (2016). Second and Foreign Language Assessment. The Modern Language Journal, 100(S1), 190-208. https:// doi.org/10.1111/modl.12308

Rose, S. B., \& Rahman, R. A. (2016). Cumulative semantic interference for associative relations in language production. Cognition, 152, 20-31.

Serrano, R. (2011). From metalinguistic instruction to metalinguistic knowledge, and from metalinguistic knowledge to performance in error correction and oral production tasks. Language Awareness, 20(1), 1-16. https://doi.org/10.1080/09658416.2010.529911

Siddiqui, S. T., Alam, S., Khan, Z. A., \& Gupta, A. (2019). Cloud-based e-learning: using cloud computing platform for an effective e-learning. In S. Tiwari, M. Trivedi, K. Mishra, A. Misra \& K. Kumar (Eds.), Smart innovations in communication and computational sciences. Advances in intelligent systems and computing, vol. 851 (pp. 335-346). Singapore, Singapore: Springer.

Sternin, I. A. (2001). Concept structure research methodology. In I. A. Sternin (Ed.), Methodological problems of cognitive linguistics (pp. 58-65). Voronezh, Russia: Voronezh State University.

Turnbull, B. (2020). Towards new standards in foreign language assessment: learning from bilingual education. International Journal of Bilingual Education and Bilingualism, 23(4), 488-498. https://doi.org/10.1080/13670050.2017.1375891

Victoria Primary School. (2018). Monitoring and Evaluating Policy. Retrieved from: ttps://storage.googleapis.com/siteassetsswd/104/downloads/Monitoring\%20a nd \%20Evaluating \%20Policy.pdf 


\section{Appendix A}

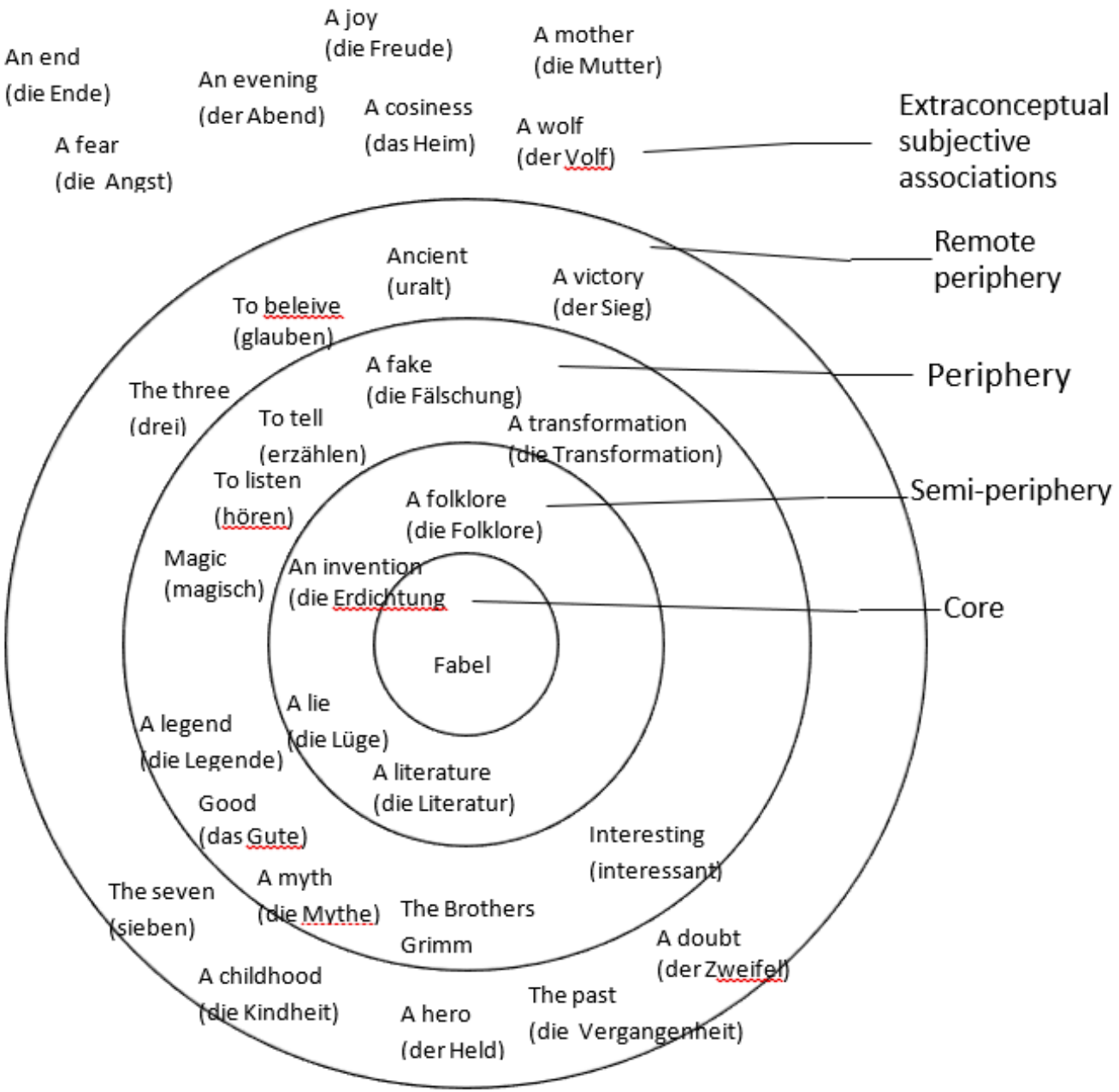

Associative-semantic field for "Fabel" (fairy tale) token 


\section{Appendix B}

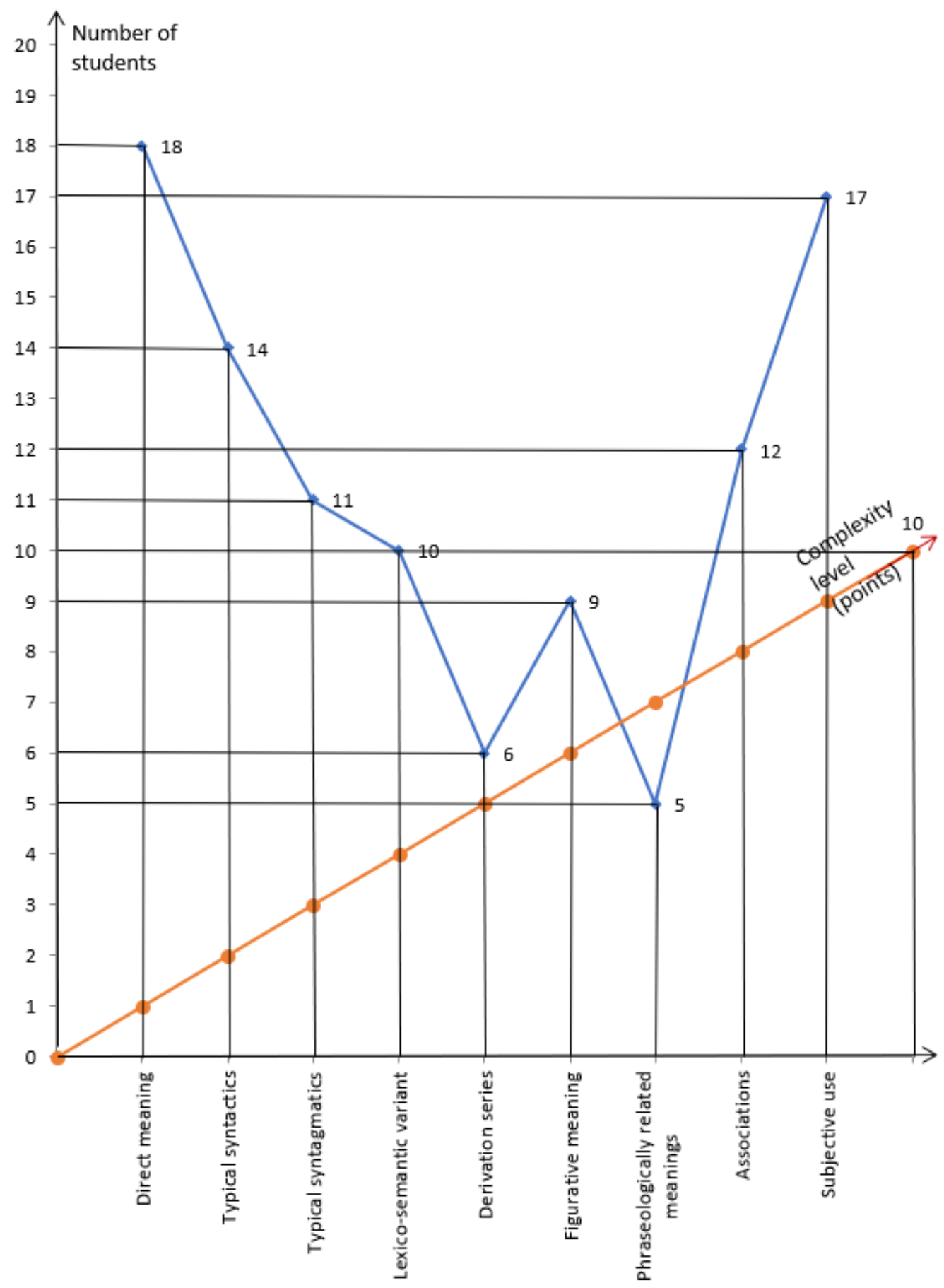

Gradation of associative uses of autonomous words in the experimental group 